\title{
公害振動の基礎事項
}

\section{1. 公害振動の概念}

一般に公害とは，事業活動その他の人為にあとづく生 活環境の侵害であって, 振動にあとづく公害とは, 振動 によって人間の生命，および健康がそてなわれ，また人 間の快適な生活が阻害されることであると考えるととが できる、したがって公害を発生させる振動は不快な振 動，乙のましくない振動と定義することができよう。こ の「不快な」という形容詞は，人間の振動に対する反応 をあらわし，振動を感じて，「不快だ」「大きい」など 上判断する主観的心理量に関係する.これに対し，「振 動」は人間の存在に関係せず存在するもので, 客観的な 物理量である. このように公害を発生させる振動は物理 的な一面と，心理的一面を有するすので，乙のような振 動分野を一応「公害振動」とよぶととにする.

非常に大きい振動とか，建物を破かいするという， あ きらかに生活環境を侵害する振動は勿論公害振動である が，一般的には，同じ振動であっても，それを感じる人 によって様々な反応を示し，ある人にとっては影響がな くてあ，他の人にとっては影響があるというようなとと が抢てる.しかしての様なことをいちいち問題にしてい ては, 公害振動を一つの客観量として取り扱うことは困 難となる.したがって振動に対する人間の反応に対して は，「平均的な人間の平均的な判断」というものを一つ の基準として採用し, 公害振動を一つの工学分野として 考えていくことになる.

この考え方は, 騒音の場合に対比させて考えると容易 に理解するととができよう。

\section{2. 振 動 波}

一般に振動波は，固体，液体などの媒質中を伝わる波 動であるが, 通常の公害振動問題において主として問題

* 石川島播磨重工業(侏防音技術センター所長
中 野 有 明*

になる地表面などを伝わる横波について考えてみると次 の様になる。

物体内の任意の一点任掁幅 $\mathrm{X}$, 周波数 $\mathrm{f}$ の正弦的変位 振動 $\mathrm{x}=\mathrm{X} \sin 2 \pi \mathrm{ft}$ がおこっているすのとする.ての変 位振動が図-1に示すようにvの速度で直線 ox の方向に 伝搬する場合を考える。

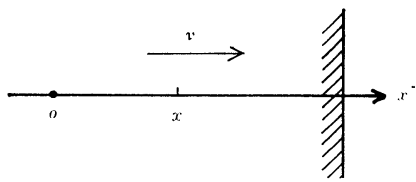

図-1

原点から $\mathrm{x}$ の距離にある任意の一点 $\mathrm{x}=\mathrm{x}$ における変 位は場所 $x$ と時間 $t$ の関数 $f(x, f)$ であるから， 0 点の 振動は(1)式のようになる.

$f(o, t)=X \sin 2 \pi f t$

$\mathrm{x}=\mathrm{x}$ に打りる振動 $\mathrm{f}(\mathrm{x}, \mathrm{t})$ は， 0 点から $\mathrm{v}$ の速度で 伝搬してきたものと考えると， $\mathrm{t}=\mathrm{t}$ のときより $\frac{\mathrm{x}}{\mathrm{v}}$ の時 間だけ前，すなわち $\left(\mathrm{t}-\frac{\mathrm{x}}{\mathrm{v}}\right)$ のときに0点にあらわれた 変位 $f\left(o, t-\frac{x}{v}\right)$ に等しいはずであり(2)式のようになる.

$$
f(x, t)=f\left(o, t-\frac{x}{v}\right)=X \sin 2 \pi f\left(t-\frac{x}{v}\right)
$$

この式から明らかなように $\mathrm{f}(\mathrm{x}, \mathrm{t})$ は $\mathrm{t}=\mathrm{t}$ のとき $\mathrm{x}$ について図-2(a)に示す $x$ の正弦曲線となり, $t=t+\Delta t$ の ときは(3)式のようになり図-2(b)のように分布する。

$$
\mathrm{f}(\mathrm{x}, \mathrm{t}+\Delta \mathrm{t})=\mathrm{X} \sin 2 \pi \mathrm{f}\left(\mathrm{t}-\frac{\mathrm{x}-\mathrm{v} \Delta \mathrm{t}}{\mathrm{v}}\right)
$$

任意の時刻 $\mathrm{t}=\mathrm{t}$ におけるある場所 $\mathrm{x}$ における変位は $\mathrm{t}=\mathrm{t}+\Delta \mathrm{t}$ のときには， $\mathrm{x}$ より $\mathrm{v} \Delta \mathrm{t}$ だけすすんだとてろ にあらわれ，時間の経過と共に变位の分布状態がそのま ま全体として速度 $\mathbf{v}$ 伝搬てていくことになる．乙の变位の分布状態が伝搬す 


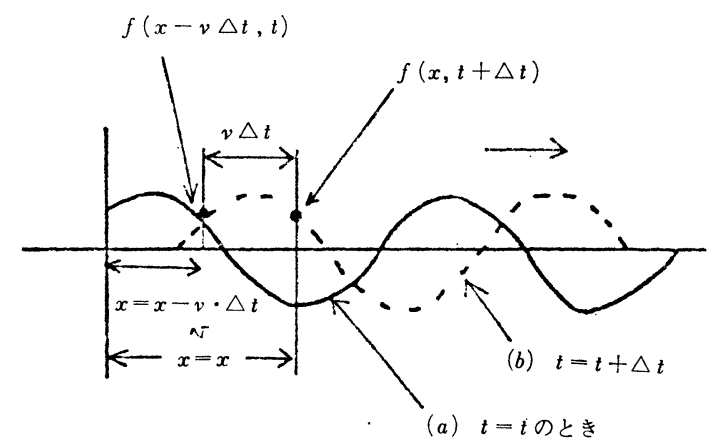

図-2 振動の伝搬

る動きが波動であり, 伀わる変位の形が波形, その速度 が伝搬速度，波形を伝える物質が媒質である。

\section{3. 振動波の伝搬速度}

たとえば正弦振動の式 $\mathrm{f}(\mathrm{x}, \mathrm{t})=\mathrm{X} \sin 2 \pi \mathrm{f}\left(\mathrm{t}-\frac{\mathrm{x}}{\mathrm{v}}\right)$ に おいて，時間 $\mathrm{t}$ が $\Delta \mathrm{t}$ だけますと共に変位 $\mathrm{x}$ が $\mathrm{v} \Delta \mathrm{t}$ だ けましたとすると, 変位 $\mathrm{f}(\mathrm{x}, \mathrm{t})$ はつぎの様になり，そ の值は変らない.

$$
\begin{aligned}
\mathrm{f}(\mathrm{x}, \mathrm{t}) & =X \sin \frac{2 \pi \mathrm{f}}{\mathrm{v}}[\mathrm{v}(\mathrm{t}+\Delta \mathrm{t})-(\mathrm{x}+\mathrm{v} \Delta \mathrm{t})] \\
& =X \sin \frac{2 \pi \mathrm{f}}{\mathrm{v}}(\mathrm{vt}+\mathrm{v} \Delta \mathrm{t}-\mathrm{x}-\mathrm{v} \Delta \mathrm{t}) \\
& =X \sin \frac{2 \pi \mathrm{f}}{\mathrm{v}}(\mathrm{vt}-\mathrm{x})
\end{aligned}
$$

これは変位 $\mathrm{f}(\mathrm{x}, \mathrm{t})$ の值が $\Delta \mathrm{t}$ 時間に距離 $\mathrm{v} \Delta \mathrm{t}$ だけ移 動する，すなわち $\mathrm{v}$ の速度で $\mathrm{x}$ の正方向に伝搬すること を示している. この $\mathrm{v}$ が振動波の伝搬速度である.

表面波の伝搬速度 $\mathrm{v}$ は普通100～ $200 \mathrm{~m} / \mathrm{s}$ である.

\section{4. 振動の周波数}

振動波は，横波の場合，媒質粒子の上下運動である が, その一秒間の振動の回数を周波数 (又は振動数) と いい，一般に記号 $\mathrm{f}$ で表わす． 単位はヘルッ $(\mathrm{Hz})$ を 用いる.

人体に感じる振動の周波数の範囲は，大体 0.1 か 500 $\mathrm{Hz}$ といわれるが, 公害振動問題では主として $1 \sim 90 \mathrm{~Hz}$ の範囲が対象になる。

\section{5. 振動波の波長}

媒質中を伝搬する振動波の変位が同じ值になる(媒質) 空間的な長さを波の長さという意味から波長という。一 般に記号入であらわす．伝搬速度を $150 \mathrm{~m} / \mathrm{s}$ とすると， 通常対象となる波長の範囲は，およそ 1.7 ～150mであ る.

\section{6. 振動波の波長, 周波数, および 伝搬速度の関係}

振動波の波長を $\lambda(\mathrm{m})$, 周波数を $\mathrm{f}(\mathrm{Hz})$, 速度を $\mathrm{v}$ $(\mathrm{m} / \mathrm{s})$ とすると，乙れらの間には $\mathrm{v}=\lambda \mathrm{f}$ の関係がある. これは次の様に導かれる，媒質中を伝わる正弦振動を $f(x, t)=X \sin \frac{2 \pi f}{v}(v t-x)$ とすると, $t=0$ すなわちある 時刻における変位の場所による変化は

$$
f(x, 0)=X \sin \frac{2 \pi f}{v} x=X \sin \frac{2 \pi}{v / f} x
$$

であり，つぎの様に $\mathrm{x}$ が $\frac{\mathrm{v}}{\mathrm{f}}$ の整数倍すすむごとに変位は 同じ值になる.

$$
\begin{aligned}
\mathrm{x} & =\frac{\mathrm{v}}{\mathrm{f}} \text { のとき } \mathrm{f}(\mathrm{x}, \mathrm{t})=\mathrm{X} \sin \frac{2 \pi}{\mathrm{v} / \mathrm{f}} \cdot \frac{\mathrm{v}}{\mathrm{f}}=\mathrm{X} \sin 2 \pi=0 \\
\mathrm{x} & =2 \cdot \frac{\mathrm{v}}{\mathrm{f}} \text { のとき } \mathrm{f}(\mathrm{x}, \mathrm{t})=\mathrm{X} \sin \frac{2 \pi}{\mathrm{v} / \mathrm{f}} \cdot 2 \frac{\mathrm{v}}{\mathrm{f}} \\
& =\mathrm{X} \sin 4 \pi=0
\end{aligned}
$$

この $\mathrm{v} / \mathrm{f}$ は変位が同じ值をとる空間的な長さである. これを入とおき波長という.すなわち $\lambda=\frac{\mathrm{v}}{\mathrm{f}} \quad \mathrm{v}=\lambda \mathrm{f}$ が 得られる.

\section{7. 振動の変位, 速度および加速度}

以上のような，振動波の，進行方向を含む鉛直面内に 振動する横波の場合，乙の振動を 正弦振動と仮定する と，振動が伝わってきたとき，地表面のある点では(4)式 で表わされる変位を生ずる.すなわち地面を伝わる表面 波の場合，ある時間について考えると，地表面に高低が できており，高いところは地面が少しもち上がり，平均 より高くなり，低のところは低くなっている，てのよう な交流的な位置の変化が変位である（図-3）.

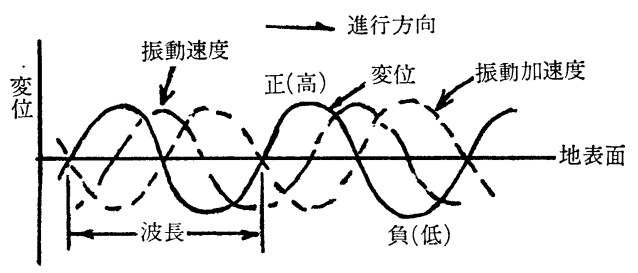

図-3 正弦振動波

$$
\mathrm{x}=\mathrm{X} \sin 2 \pi \mathrm{ft}
$$

$(\mathrm{x}$ : 変位振幅の瞬時値, $\mathrm{X}$ : 変位振幅の最大值, $\mathrm{f}:$ 周 波数)

したがってその点の振動速度，また振動加速度はそれ ぞれ

$$
\begin{aligned}
& \dot{x}=2 \pi f \cdot X \cdot \cos 2 \pi f t \\
& \ddot{x}=-(2 \pi f)^{2} \cdot X \cdot \sin 2 \pi f t
\end{aligned}
$$


となる。

$$
2 \pi \mathrm{fX}=\mathrm{V}_{\mathrm{m}}, \quad-(2 \pi \mathrm{f})^{2} \mathrm{X}=\mathrm{A}_{\mathrm{m}}
$$

とおくと, これらは

$\dot{\mathrm{x}}=\mathrm{V}_{\mathrm{m}} \cos 2 \pi \mathrm{ft}$

$\ddot{\mathrm{x}}=\mathrm{A}_{\mathrm{m}} \sin 2 \pi \mathrm{ft}$

となる， $\mathrm{V}_{\mathrm{m}} ， \mathrm{~A}_{\mathrm{m}}$ はそれぞれ振動速度および加速度の最 大值を表わす. 振動速度は媒質の変位の時間的変化であ る. 振動加速度は媒質の振動速度の变化であり, 変位の 小さいとき加速度は最大，大きいとき最小となる交流的 変化である.

\section{8. 振動加速度実効值}

公害振動問題においては，振動の強弱を表わす基本的 尺度として振動加速度の実効值を使用する。一般に周期 $\mathrm{T}$ をつつ時間関数 $f(t)$ の実効值は,

$\mathrm{A}=\sqrt{\frac{1}{\mathrm{~T}} \int_{0}^{\mathrm{T}}[\mathrm{f}(\mathrm{t})]^{2} \mathrm{dt}}$ で表わされる. 振動加速度を $\mathrm{a}=\mathbf{A}_{\mathrm{m}} \sin 2 \pi \mathrm{ft}$ とすると振動加速度の実効值 $\mathrm{A}$ は $\mathrm{A}=\frac{\mathrm{A}_{\mathrm{m}}}{\sqrt{2}}$ となる。この一定加速度が刺激となって我々は 振動を感じる(図-4).

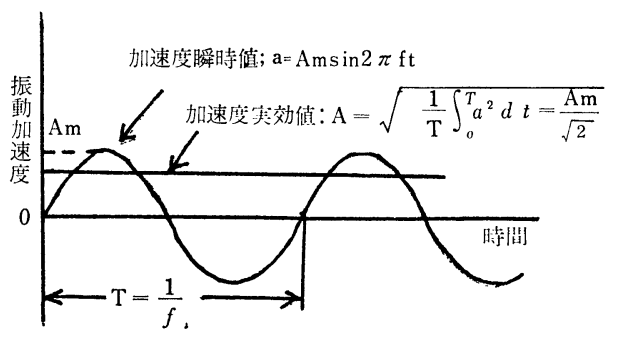

図-4 加速度の瞬時値と実効值

振動加速度の大きい振動は強い振動, 小さい振動は弱 い振動を意味する. 通常実効值で $10^{-2} \mathrm{~m} / \mathrm{s}^{2}$ から $10 \mathrm{~m} / \mathrm{s}^{2}$ 程度の範囲が対象となる。

\section{9. 振動加速度レベル}

公害振動問題を考えていく場合, 実用的には通常つぎ にのベる振動加速度レベルが用いられる．しかしてれは 前記の振動加速度が形を変えただけであり, 振動の物理 量のあっとあ基本的なむのであるととに変わりはない.

振動加速度（実効值, 以下とくにととわらない限り実 効值之する)を $\mathrm{A}\left(\mathrm{m} / \mathrm{s}^{2}\right)$, 振動加速度の基準值を $\mathrm{A}_{0}\left(\mathrm{~m} / \mathrm{s}^{2}\right)$ とすると振動加速度レベル Lは, $\mathrm{L}=20 \log _{10} \frac{\mathrm{A}}{\mathrm{A}_{0}}(\mathrm{~dB})$ で定義される.
単位は $\mathrm{dB}$ (デシベル) である. $\mathrm{A}_{0}$ としてはふつう人 体の全身掁動*の最小可覚值（人体の感じうる最小の振 動加速度, 周波数 $4 \sim 8 \mathrm{~Hz}$ の鉛直振動の場合, 約 $10^{-2}$ $\mathrm{m} / \mathrm{s}^{2}$ である) $10^{-2} \mathrm{~m} / \mathrm{s}^{2}$ の $1 / 1000$ ，すなわち $10^{-5} \mathrm{~m} / \mathrm{s}^{2}$ が 用いられる. 振動加速度レベルの大きい振動は強い振 動, 小さい振動は弱い振動である.ふつうは $60 \mathrm{~dB}$ から $120 \mathrm{~dB}$ 程度の範囲が対象になる。

\section{0. 振動のレベルの和, 差, 平均の計算}

\section{1）レベルの和}

振動加速度レベル（以下加速度レベルとする） $\mathrm{L}_{1}, \mathrm{~L}_{2}$ （dB）をむつ周波数の異なる二つの振動波の和のレベル しは次式になる。

$$
\begin{aligned}
& \mathrm{L}=10 \log \left(10^{\left.\frac{\mathrm{L}_{1}}{10}+10^{\frac{\mathrm{L}_{2}}{10}}\right)}\right. \\
& =\mathrm{L}_{1}+10 \log _{10}\left(1+10^{-\frac{\Delta \mathrm{L}}{10}}\right) \\
& \text { ただし } \Delta \mathrm{L}=\mathrm{L}_{1}-\mathrm{L}_{2}\left(\mathrm{~L}_{1} \gg \mathrm{L}_{2}\right) \text { である. }
\end{aligned}
$$

$\Delta \mathrm{L}$ と $\alpha=10 \log _{10}\left(1+10^{-\frac{\Delta \mathrm{L}}{10}}\right)$ の関係は表 1 の様になる.

表 $1 \quad \mathrm{~L}_{1}(\mathrm{~dB})$ と $\mathrm{L}_{2}(\mathrm{~dB})$ の和の計算

$\left(\mathrm{L}_{1}(\mathrm{~dB})\right.$ 之 $\mathrm{L}_{2}(\mathrm{~dB})$ の差は $\left.\mathrm{L}_{1} \geq \mathrm{L}_{2}\right)$

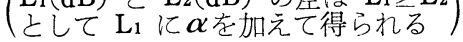

\begin{tabular}{c|c|c|c|c|c|c|c|c|c|c|c|c}
\hline $\mathrm{L}_{1}$ 亡 $\mathrm{L}_{2}$ & 0 & 1 & 2 & 3 & 4 & 5 & 6 & 7 & 8 & 9 & 10 & 11 \\
\hline$\alpha$ & 3.0 & 2.5 & 2.1 & 1.8 & 1.5 & 1.2 & 1.0 & 0.8 & 0.6 & 0.5 & 0.4 & 0.3 \\
\hline & & &
\end{tabular}

\section{上式は次の様に導かれる（図-5）.}

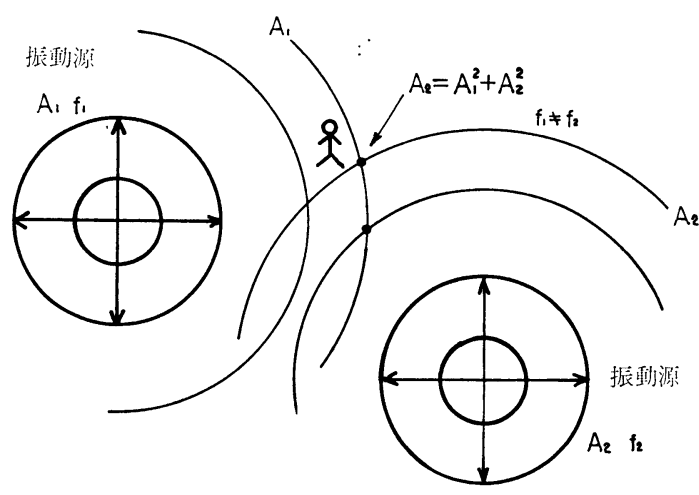

図-5 周波数の異なる 2 つ振動波の合成

*ここでいら全身振動感覚は, 立った人の足, すわった人 の腰など, 振動か人体の支持部を通して全身に伝わる場 合の振動感覚である. 
定義から $\mathrm{L}_{1}=20 \log _{10} \frac{\mathrm{A}_{1}}{\mathrm{~A}_{0}}, \mathrm{~L}_{2}=20 \log _{10} \frac{\mathrm{A}_{2}}{\mathrm{~A}_{0}}(\mathrm{~dB})$ で ある・

ただし $\mathrm{A}_{1} ， \mathrm{~A}_{2}$ はそれぞれの振動加速度である。これ らの式から $\mathrm{A}_{1}, \mathrm{~A}_{2}$ を求めると夫々 $\mathrm{A}_{1}=\mathrm{A}_{0} \cdot 10^{\frac{\mathrm{L}_{1}}{10}}, \mathrm{~A}_{2}=$ $\mathrm{A}_{0} \cdot 10^{\frac{\mathrm{L} 2}{10}}$ となる。

これから合成振動の加速度 $\mathrm{A}$ は $\mathrm{A}^{2}=\mathrm{A}_{1}{ }^{2}+\mathrm{A}_{2}{ }^{2}$ すなお ち $\mathrm{A}=\sqrt{\mathrm{A}_{1}{ }^{2}+\mathrm{A}_{2}{ }^{2}}$ となるから合成振動の 加速度レベル Lすなわち和のレベルは

$\mathrm{L}=20 \log _{10} \frac{\mathrm{A}}{\mathrm{A}_{0}}=20 \log _{10} \sqrt{\frac{\mathrm{A}_{1}^{2}+\mathrm{A}_{2}^{2}}{\mathrm{~A}_{0}^{2}}}=10 \log _{10} \frac{\mathrm{A}_{1}^{2}+\mathrm{A}_{2}^{2}}{\mathrm{~A}_{0}{ }^{2}}$ $=10 \log _{10} \frac{A_{0}^{2}\left(10^{\frac{L_{1}}{10}}+10^{\frac{L_{2}}{10}}\right)}{A_{0^{2}}^{2}}=10 \log _{10}\left(10^{\frac{L_{1}}{10}}+10^{\frac{L_{2}}{10}}\right)$

となる.乙の式で $\Delta \mathrm{L}=\mathrm{L}_{1}-\mathrm{L}_{2}$ とおき $\mathrm{L}_{2}=\mathrm{L}_{1}-\Delta \mathrm{L}$ を 代入して計算すると

$\mathrm{L}=10 \log _{10}\left(10^{\frac{\mathrm{L}_{1}}{10}}+10^{\frac{\mathrm{L}_{1}-\Delta \mathrm{L}}{10}}\right)=10 \log _{10} 10^{\frac{\mathrm{L}_{1}}{10}}\left(1+10^{-\frac{\Delta \mathrm{L}}{10}}\right)$

$$
=\mathrm{L}_{1}+10 \log _{10}\left(1+10^{-\frac{\Delta \mathrm{L}}{10}}\right)
$$

が得られる。

いくつかのレベルの和を求める場合は，はじめの二つ のレベルの和を求め,つぎにこの結果と他の一つのレベ ルの和を求め, 以下同様にして順次和を求めていけばよ い.

\section{2）レベルの算術平均とパワー平均}

二つの振動加速度レベル $\mathrm{L}_{1}, \mathrm{~L}_{2}(\mathrm{~dB})$ の算術平均值 $\mathrm{L}_{\mathrm{m}}$ は次式で求められる.

$$
\mathrm{L}_{\mathrm{m}}=\frac{\mathrm{L}_{1}+\mathrm{L}_{2}}{2}
$$

またパワー平均值 $\overline{\mathrm{L}}(\mathrm{dB})$ は次式の様になる。

$$
\overline{\mathrm{L}}=10 \log _{10}\left(10^{\frac{\mathrm{L}_{1}}{10}}+10^{\frac{\mathrm{L}_{2}}{10}}\right)-10 \log _{10} 2
$$

すなわち二つのレベルのパワー平均值は, 二つのレベル の和のレベルから平均する数（この場合は 2 ) の常用対 数の10倍, $10 \log _{10} 2$ を引いた値となる.

すなわち $\mathrm{L}_{1}=20 \log _{10} \frac{\mathrm{A}_{1}}{\mathrm{~A}_{0}}, \mathrm{~L}_{2}=20 \log _{10} \frac{\mathrm{A}_{2}}{\mathrm{~A}_{0}}$ である 加ら, $\mathrm{A}_{1}=\mathrm{A}_{0} \cdot 10^{\frac{\mathrm{L}_{1}}{20}}, \mathrm{~A}_{2}=\mathrm{A}_{0} \cdot 10^{\frac{\mathrm{L}_{2}}{20}}$, 平均の 加速度 $\overline{\mathrm{A}}$ は $\overline{\mathrm{A}}^{2}=\frac{\mathrm{A}_{1}{ }^{2}+\mathrm{A}_{2}{ }^{2}}{2} \therefore \overline{\mathrm{A}}=\sqrt{\frac{\mathrm{A}_{1}^{2}+\overline{\mathrm{A}}_{2}^{2}}{2}}$ であるから平均の 加速度レベル $\overline{\mathrm{L}}$ は $\overline{\mathrm{L}}=20 \log _{10} \frac{\overline{\mathrm{A}}}{\mathrm{A}_{0}}=20 \log _{10} \sqrt{\frac{\mathrm{A}_{1}^{2}+\mathrm{A}^{2}{ }_{2}}{2 \mathrm{~A}_{0}{ }^{2}}}$ $=10 \log _{10} \frac{\mathrm{A}_{1^{2}}+\mathrm{A}_{2}{ }^{2}}{2 \mathrm{~A}_{0}{ }^{2}}=10 \log _{10} \frac{\mathrm{A}_{0}^{2}\left(10^{\frac{\mathrm{L}_{1}}{10}}+10^{\frac{\mathrm{L}_{2}}{10}}\right)}{2 \mathrm{~A}_{0}^{2}}$
$=10 \log _{10}\left(10^{\frac{\mathrm{L}_{1}}{10}}+10^{\frac{\mathrm{L}_{2}}{10}}\right)-10 \log _{10} 2$ となる.

両者の関係は

$$
\overline{\mathrm{L}}-\mathrm{L}_{\mathrm{m}}=10 \log _{10}\left(1+10^{-\frac{\Delta \mathrm{L}}{10}}\right)+\frac{\Delta \mathrm{L}}{2}-3
$$

\section{で表わされる.}

相互のレベル差が大きい場合には，その算術平均值は 真の平均值をあらわさないので, パワー平均值を求めな ければならない，ただし上式からわかる様に，レベル差 が $5 \mathrm{~dB}$ 以内であれば算術平均值を用いてあ大差ない (レベル差が $5 \mathrm{~dB}$ で， $\mathrm{L}_{\mathrm{m}}$ は $\overline{\mathrm{L}}$ より $0.7 \mathrm{~dB}$ 小さい).

\section{3）レベルの差}

二つの加速度レベル $\mathrm{L}_{1}(\mathrm{~dB})$ と $\mathrm{L}_{2}(\mathrm{~dB})$ の差のレベ ル $\mathrm{L}^{\prime}$ は, 次式で求められる。

$$
\begin{aligned}
L^{\prime} & =10 \log _{10}\left(10^{\frac{\mathrm{L}_{1}}{10}}-10^{\frac{\mathrm{L}_{2}}{10}}\right) \\
& =\mathrm{L}_{1}+10 \log _{10}\left(1-10^{-\frac{\Delta \mathrm{L}}{10}}\right)
\end{aligned}
$$

$\Delta \mathrm{L}$ と $\mathrm{N}=10 \log _{10}\left(1-10^{-\frac{\Delta \mathrm{L}}{10}}\right)$ の関係は表 2 の様にな る.

表 $2 \mathrm{~L}_{1}(\mathrm{~dB})$ と $\mathrm{L}_{2}(\mathrm{~dB})$ の差の計算表

\begin{tabular}{l|c|c|c|c|c|c|c}
\hline $\begin{array}{c}\mathrm{L}_{1}^{\text {の差 }} \mathrm{L}_{2} \\
\mathrm{~N}\end{array}$ & 3 & 4 & 5 & 6 & 7 & 8 & 9 \\
\hline $\mathrm{N}$ & -3.0 & -2.3 & -1.7 & -1.25 & -0.95 & -0.75 & -0.60 \\
\hline 四捨五入 & -3 & -2 & \multicolumn{3}{|c}{-1} \\
\hline
\end{tabular}

上式はつぎの様に求められる.

$L_{1}=10 \log _{10} \frac{A_{1}}{A_{0}}, L_{2}=10 \log _{10} \frac{A_{2}}{A_{0}}$ であるから

$\mathrm{A}_{1}=\mathrm{A}_{0} \cdot 10^{\frac{\mathrm{L}_{1}}{20}}, \mathrm{~A}_{2}=\mathrm{A}_{0} \cdot 10^{\frac{\mathrm{L} 2}{20}}$

差の加速度 $\mathrm{A}^{\prime}$ は $\mathrm{A}^{\prime 2}=\mathrm{A}_{1}^{2}-\mathrm{A}_{2}{ }^{2} \quad \therefore \mathrm{A}^{\prime}=\sqrt{\mathrm{A}_{1}{ }^{2}-\mathrm{A}_{2}{ }^{2}}$

差のレベル $L^{\prime}$ は $\mathrm{L}^{\prime}=20 \log _{10} \frac{\mathrm{A}^{\prime}}{\mathrm{A}_{0}}=20 \log _{10} \sqrt{\frac{\mathrm{A}_{1}^{2}-\mathrm{A}_{2}{ }^{2}}{\mathrm{~A}_{0}{ }^{2}}}$ $=10 \log _{10} \frac{\mathrm{A}_{1}^{2}-\mathrm{A}_{2}^{2}}{\mathrm{~A}_{0}}=10 \log _{10} \frac{\mathrm{A}_{0}\left(10^{\frac{\mathrm{L}_{1}}{10}}-10^{\stackrel{\mathrm{L}_{2}}{10}}\right)}{\mathrm{A}_{0}{ }^{2}}$ $=10 \log _{10}\left(10^{\frac{L_{1}}{10}}-10^{\frac{L_{2}}{10}}\right)$

$\Delta \mathrm{L}=\mathrm{L}_{2}-\mathrm{L}_{1}$ とおくと $\mathrm{L}_{2}=\mathrm{L}_{1}-\Delta \mathrm{L}$, 乙れを上式に代 入して $L^{\prime}=10 \log _{10}\left(10^{\frac{\mathrm{L} 1}{10}}-10^{\frac{\mathrm{L}_{1}-\Delta \mathrm{L}}{10}}\right)$ $=10 \log _{10} 10^{\frac{\mathrm{L}_{1}}{10}}\left(1-10^{-\frac{\Delta \mathrm{L}}{10}}\right)=\mathrm{L}_{1}+10 \log _{10}\left(1-10^{-\frac{\Delta \mathrm{L}}{10}}\right)$ となる・ 
$\mathrm{L}_{1}(\mathrm{~dB})$ を対象の振動と暗振動（ある場所において， 特定の振動を対象として考える場合に, 対象の振動がな いときのその場所における振動のととである）のレベル の和, $\mathrm{L}_{2}(\mathrm{~dB})$ を暗振動のみのレベルとすると, レベル 差の計算は暗振動の補正計算となる.

\section{1. 振動スペクトル}

実際にそう遇する振動の多くは，勝手な時間的変化を していると考えられる。いいろな周波数成分からなる 複合掁動である.とのような振動を表示する場合, 一般 に横軸に周波数をとり，たて軸に振運加速度レベルをと って，その振動を構成する周波数成分ごとに，その振動 加速度レベルをプロットして表示する．てのように振動 を周波数ごとの振動加速度レベルで表示したものを振動 スペクトルという. 公害振動の分野では，横軸の周波数 範囲をオクターブまたは $1 / 3$ オクターブバンド幅の周波数 バンドにわけ，そのバンドを代表する中心周波数でと に，そのバンド内の振動加速度レベルをプロットして図 -6のように表示するのが普通である.

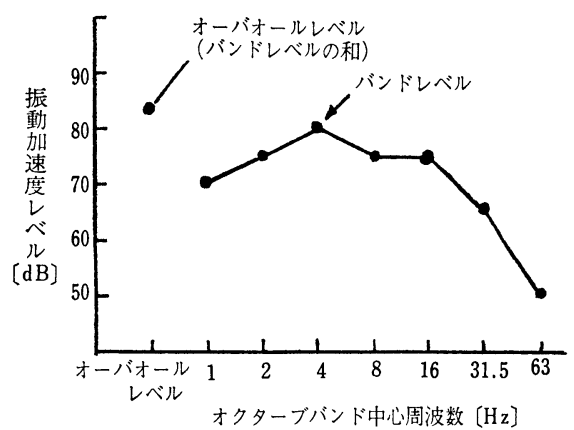

(a) オクターブバンドスペクトルの場合

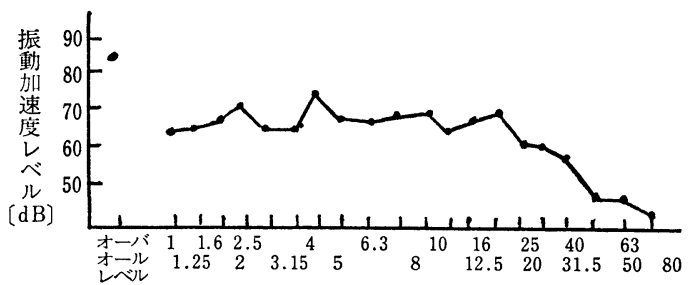

(b) $1 / 3$ オクターブバンドスペクトルの場合

図-6＼cjkstart振動スペクトルの一例

\section{2. オクターブバンドと中心周波数}

周波数バンドの幅，中心周波数，およびバンドの両端 の周波数（しゃ断周波数，または切断周波数）は，表 3 のように国際的に决められている.
表 3 オクターブおよび1/3オクターブ中心 周波数としゃ断周波数 (単位 $\mathrm{Hz}$ )

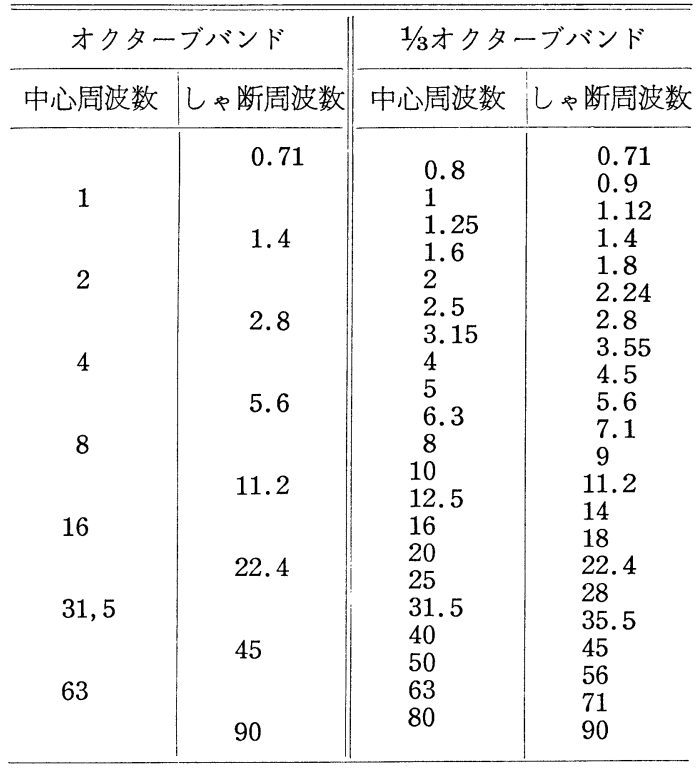

一般に二つの周波数 $f_{i+1}, f_{i}(i=1 \sim n)(H z)$ の間に $\frac{f_{i+1}}{f_{i}}=2^{n}$ の関係が成り立つとき $f_{i+1}$ は $f_{i}$ より $n$ オク ターブ高いという. $\mathrm{n}=1$ の場合がオクターブで $\mathrm{f}_{\mathrm{i}+1}=$ $2 \mathrm{f}_{\mathrm{i}}$ となる.オクターブバンドとはこのような関係の二 つの周波数 $\mathrm{f}_{\mathrm{i}}, \mathrm{f}_{\mathrm{i}+1}$ ，すなわち $\mathrm{f}_{\mathrm{i}}$ と $2 \mathrm{f}_{\mathrm{i}}$ をバンドの両 端の周波数とする周波数バンドにわけたものをいう.1/3 オクターブバンドの場合は $\mathrm{n}=1 / 3$ とおき, $\mathrm{f}_{\mathrm{i}+1}=\sqrt[3]{2 \mathrm{f} i}$ となる。

バンドの中心周波数 $\mathrm{f}_{0 \mathrm{i}}$ は高, 低域しゃ断周波数 $\mathrm{f}_{\mathrm{i}+1}$, $f_{i}$ から $f_{0 i}=\sqrt{f_{i} \cdot f_{i+1}}(H z)$ で求められる.

\section{3. オーバオールレベルとバンドレベル}

振動を感じる場合, 各周波数バンドの振動を一つずつ 別々に感じるわけではなく，乙れらが合成された全体を 一つの振動として感じることになる．ての合成された全 体の振動のレベルをオーバオール（全域）振動加速度レ ベルという. とれに対して各バンドのレベルをバンドレ ベルという.オーバオールレベルは10，1)の方法でバン ドレベルの和を求めることによって得られる.

図-6 の場合は各バンドレベルを $\mathrm{L}_{\mathrm{i}}(\mathrm{i}=1$ ～7) $(\mathrm{dB})$ と するとオーバオールレベル L(dB) は

$\mathrm{L}=10 \log _{10}\left(\sum_{\mathrm{i}=1}^{7} 10^{\frac{\mathrm{L}_{\mathrm{i}}}{10}}\right)(\mathrm{dB})$ と求まる.

\section{4. 振動レベル}

公害振動の物理的性質は振動スペクトル，すなわち周 
波数バンド毎の掁動加速度レベルで表わすととができる が，これは単なる物理量であり，振動に対する人間の反 応は入っていない. 振動をうけた場合の人間の判断, 感 じなどの主観的心理量は，心理実験によって物理量と結 びつけられるが，結局は，振動を構成する各周波数バン ドの加速度レベルに対して，周波数による重みをつける ということになる。

振動スペクトルに対する重みの周波数特性は, ISO 提 案による図一ーに示されるものが現在使用されているが， これは, ランダム振動に対する全身振動の等感度曲線に あとづくあので, 鉛直振動の場合は, 周波数 $4 \sim 8 \mathrm{~Hz}$ の間は平坦， $4 \mathrm{~Hz}$ 以下は，周波数が $1 / 2$ 倍になるごとに 加速度レベルが $3 \mathrm{~dB}$ づつ減少し， $8 \mathrm{~Hz}$ 以上は周波数 が 2 倍になるごとに $6 \mathrm{~dB}$ づつ減少する特性である. 水 平掁動の場合は， $1 \sim 2 \mathrm{~Hz}$ は平坦， $2 \mathrm{~Hz}$ 以上は周波 数が 2 倍になるごとに $6 \mathrm{~dB}$ づつ減少する特性である.

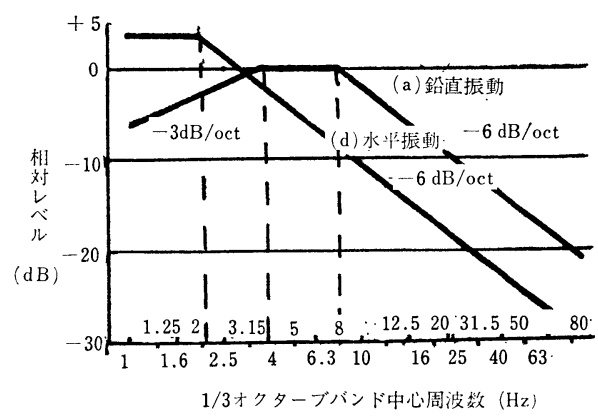

図-7 垂直および水平振動の等感度曲線（ISO）

各周波数バンドの加速度レベルにこのような重みをつ けて得られるレベルの和を10，1）の方法によって求め ると, オーバオールレベルが得られるが，乙れが振動レ ベルである. 振動レベルは単なる物理量であるオーバオ 一ル振動加速度レベルと異なって, 振動感覚の補正を行 なって得られる振動加速度レベルであり, 公害振動の大 きさの尺度として用いらる。これは JIS-C-1510 掁動レ
ベル計の指示値として得られる。

なお振動規制法においてはこの振動レベルを補正加速 度レベルとよんで，鉛直振動の 周波数を $\mathrm{f}(\mathrm{Hz})$ ，加速 度を $\mathrm{A}\left(\mathrm{m} / \mathrm{s}^{2}\right)$ とするとき $\mathrm{A}$ の下記に示す基準值 $\mathrm{A}_{0}(\mathrm{~m}$ $\left./ \mathrm{s}^{2}\right), \quad \mathrm{A}_{0}=2 \times 10^{-5} \mathrm{f}^{-1 / 2}(1 \leqq \mathrm{f} \leqq 4), \quad \mathrm{A}_{0}=10^{-5}(4 \leqq \mathrm{f} \leqq 8)$, $\mathrm{A}_{0}=0.125 \times 10^{-5} \mathrm{f}(8 \leqq \mathrm{f} \leqq 90)$ 亿対する比の常用対数の 20 倍すなわち $20 \log _{10} \frac{\mathrm{A}}{\mathrm{A}_{\mathbf{0}}}(\mathrm{dB})$ であらわしたものと定義 しているが, 同じものである.

多くの実際の振動において，鉛直方向振動レベル $\mathrm{L}_{\mathbf{v}}$ (dB) は振動速度のピーク值を $\mathrm{V}(\mathrm{m} / \mathrm{s})$ とすると $\mathrm{L}_{\mathrm{v}}=$ $20 \log _{10} \mathrm{~V}+129(\mathrm{~dB})$ で求められる.

\section{5. $10 \%$ 值，中央値など}

振動計の指示值が不規則且つ大幅に変動する振動や， 掁動計の指示值が周期的間欠的に変動し，その指示值の 最大值が一定でない振動の場合，その振動の大きさを定 めるために，たとえば振動規制法では10\%值 $\mathrm{L}_{10}$ という ものが用いられている.

これは次の様なあのである.

まずこの様に変動する振動を短い一定時間隔毎に例え ば100コ測定する.とのデータをむとに，振動レベルの低 いものから累積をして, 累積度数を求める. この累積度 数の $90 \%$ 亿相当する振動レベルが10\%值， $\mathrm{L}_{10}$ である. これはまた $80 \%$ レンジの上端值に相当する.

一般に $\mathrm{x} \%$ 值 $\mathrm{L}_{\mathrm{x}}$ とは，累積度数の $(100-\mathrm{x}) \%$ 相 当する振動レベルであり，てれはまた $(100-2 \mathrm{x}) \%$ レン ジの上端值に相当する振動レベルである.また $50 \%$ 值す なわち累積度数の $50 \%$ に相当する振動レベルが中央值で ある。

\section{参考 文 献}

中野：騒音対策 付公害振動資料 情 報企 画センター出 版 部 (1975)

中野：騒音（振動）測定試験方法 同上 (1976)

中野 : 音響技術 $(1972-7)$

中野 : 音響学会誌 29 巻11号 (1973)

中野： " 30巻 1 号 (1974) 